\title{
Instalasi Framework IoT Berbasis Platform Thingsboard di Ubuntu Server
}

\author{
Gede Humaswara Prathama ${ }^{1}$, Dhipa Andaresta ${ }^{2}$, Kadek Darmaastawan ${ }^{3}$ \\ ${ }^{123}$ Program Studi Teknologi Informasi, Fakultas Teknik dan Informatika, Universitas Pendidikan Nasional
}

\begin{abstract}
Technology is made to make it easier for humans to do various types of work. One technology that is very popular today is the Internet of Things. The application of Internet of Things technology is widely used in various fields at this time. One example is in the fields of agriculture and health. Internet of Things in this field is usually used for monitoring or control systems. To make it easier to control, especially in showing the results of the controlled data, using Thingsboard is one way. Thingsboard has two main functions, namely as a broker in IoT terminology (core services) and as a data presenter (web User Interface). Thingsboard also provides several examples of projects that might approach the need and also provides an installer that can be installed on a computer, for example with Windows OS, Linux, or on a Raspberry Pi.
\end{abstract}

Keywords: Internet of Things; Control systems; Linux

\begin{abstract}
ABSTRAK
Teknologi dibuat untuk mempermudah manusia melakukan berbagai jenis pekerjaan. Salah satu teknologi yang sangat populer pada saat ini yaitu Internet of Things. Penerapan teknologi Internet of Things banyak digunakan di berbagai bidang pada saat ini. Salah satu contohnya yaitu di bidang pertanian dan kesehatan. Internet of Things di bidang tersebut biasanya digunakan untuk melakukan monitoring atau sistem kontrol. Untuk mempermudah melakukan kontrol khususnya dalam memperlihatkan hasil data yang dikontrol tersebut, menggunakan Thingsboard adalah salah satu caranya. Thingsboard memiliki dua fungsi utama yaitu sebagai broker di dalam terminologi IoT (core services) dan sebagai penyaji data (web User Interface). Thingsboard juga memberikan beberapa contoh project yang mungkin mendekati kebutuhan dan juga menyediakan installer yang bisa diinstal di komputer contohnya yaitu dengan OS Windows, Linux, atau di Raspberry Pi.
\end{abstract}

Keywords: Internet of Things; Sistem Kontrol; Linux

\section{Info Artikel}

Diterima Redaksi : $\quad$ 01-11-2021

This is an open access article under the $\underline{C C B Y-S A}$ license.

Selesai Revisi : 01-12-2021

Diterbitkan Online $\quad: \quad 30-12-2021$

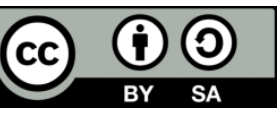

\section{Penulis Korespondensi:}

I Gusti Gede Dhipa Andaresta

Teknologi Informasi,

Universitas Pendidikan Nasional,

Jalan Mertha Agung Gg. Madusari No. 36, Kerobokan, 80117.

Email: dipaandaresta@gmail.com

\section{PENDAHULUAN}

Digita lisasi industri 4.0 berkembang dengan pesat, Pesatnya Digita lisa si industri ini berpengaruh pada semua a spek, antara la in a spek sosial, ekonomi dan teknologi. Perkembangan didalam dunia industri ini harus dipahami sebagai jalan untuk mencapai tujuan yang lebih penting, yaitu menciptakan kesejahteraan sosial. 
Pada tahap revolusi industri tahap empat ini ditandai dengan berbagai teknologi yang menggabungkan dunia fisik, digital, dan biologis yang mempengaruhi semua disiplin ilmu, yaitu kehidupan perekonomian, aktivitas industri, dan kapasitas tenaga kerja. Adapun basis orientasi dari industri tahap empat adalah otomatisasi digitalisasi yang membuat proses produksi semakin efisien dengan kualitas produk lebih baik, sehingga meningkatkan kemampuan bersaing. Beberapa teknologi yang berperan di dalam industri 4.0, ini yaitu advanced robotic, additive manufacturing, augmented reality, simulation, horizonal/vertical integration, industrial internet, cloud, cyber security, big data dan analytics.

Internet of Things atau biasa disebut IoT adalah sebuah ga ga san dimana semua benda yang berada di dunia nyata dapat berkomunikasi satu sama lain dan merupakan bagian dari satu kesatuan sistem yang menggunakan jaringan internet sebagai penghubung. Misalnya CCTV yang terpasang di sebuah rumah dan dihubungkan dengan koneksi internet lalu disatukan di rung kontrol yang jaraknya mungkin puluhan kilometer[1]. Pada dasarnya perangkat IoT terdiri dari sensor sebagai media pengumpul data, sambungan internet sebagai media komuniakasi dan server sebagai pengumpul informasi yang diterima sensor dan untuk analisa. Sejak dicetuskannya istilah IoT pada tahun 1999, Internet of things (IoT) telah berubah dari sekadar visi menjadi realitas. Hal ini berkaitan dengan luasnya penggunaan Internet Protocol (IP), munculnya komputa si dimana-mana, dan kemajuan analisis data tingkat lanjut. Menurut data Juniper Research pada tahun 2020, a da 35 miliar perangkat Internet of Things (IoT) dengan konektivitas dan berkomunika si tanpa interaksi dengan manusia[2].

Pesatnya perkembangan IoT tidak luput dari berkembang pesa tnya perangkat keras, perangkat lunak, hingga muatan informasi yang beredar di da la mnya. Sistem opera si sebagai penghubung antara perangkat keras dan perangkat lunak merupakan suatu komponen penting di dalam dunia teknologi. Sistem operasi di suatu server memerlukan ketangguhan dan kemampuan yang tinggi untuk menyediakan layanan-la yanan yang ada, sehingga server tersebut dapat mendukung kinerja sistem informasi. Ubuntu sebagai salah satu sistem operasi terna ma memiliki sa tu distribusi yang didesa in khusu s untuk server yang disebut Ubuntu Server. Sistem opera si ini memberikan berbagai kelebihan dan keunggulan dibanding sistem operasi server lain. Mulai dari mudahnya mengeoperasikan server, kestabilan penggunaan server, hingga dukungan komunitas dan yang sangat luas sehingga mendukung pengembangan sistem informasiyang berbasis pada platform linux ini[3].

Ubuntu server sebagai sistem operasi server tak lepas kaitannya dengan berbagai aplikasi-aplikasi yang tersedia dalam hal menyediakan layanan. Berbagai aplikasi server tersedia untuk dapat dipergunakan pada ubuntu server mulai dari sistem web server, basis data, file sharing hingga berbagai perangkat lunak penyedia layanan lain yang sering dipergunakan diatas sistem operasi ubuntu server. Ubuntu server sebagaimana dijelaskan sebelumnya memiliki dukungan terhadap jaringan yang begitu luas. Ubuntu server sebagai sistem berbasis linux menggunakan TCP/IP sebagai protokol komunikasiantarkomputer. Dalam hal ini selain sebagai client pada jaringan, ubuntu server juga dapat memberikan layanan di bidang jaringan. Layanan tersebut diantaranya a dalah: Routing, Dynamic Host Configuration Protocol (DHCP), Domain Name Service (DNS), Proxy Server, Firewall, OpenSSH Server, File Sharing, FTP Server, Web Server, Databases Server, Email Services. Pengguna an linux sebagai router telah dikenal sejak lama. Sistem opera si ubuntu server yang cukup ringan dan stabil juga memiliki kemampuan untuk dimanfaatkan sebagai router. Dengan melakukan forwarding paket-paket data dari satu segmen jaringan ke segmen jaringan lain memungkinkan ubuntu server melakukan fungsi sebagai router[3].

\section{METODE PENELITIAN}

Pada penelitian ini bertujuan untuk melakukan proses Instalasi Thingsboard di Ubuntu Server. Instalasi dilakukan dengan menginstall terlebih dahulu Oracle VM VirtualBox. Setelah selesai menginstall VirtualBox, yang dibutuhkan selanjutnya yaitu menginstall Ubuntu Server. Instalasi Thingsboard dilakukan sesuai dengan arahan yang ada di Thingsboard Documentation [4].

\subsection{ThingsBoard}


ThingsBoard merupakan sebuat platform Internet of Things (IoT) yang bersifat open source. ThingsBoard ini juga merupakan web server yang dapat digunakan sebagai platform manajemen device, pengumpulan data, dan visualisasi data berbasis website. ThingsBoard juga memiliki dua fungsi utama yaitu sebagai broker dalam terminologi Internet of Things (core services) dan sebagai web presentation/penyaji data(web UI). Thingsboard memungkinkan pengguna untuk melakukan perancangan dan konfigurasi dashboard Internet of Things (IoT) yang dapat disesuaikan dengan kebutuhan dan keinginan pengguna. Dashboard perangkat di Thingsboard biasanya berisi widget yang memvisualisasikan data telemetri dari perangkat Internet of Things (IoT) yang berbeda. ThingsBaord juga mendukung enkripsi transport untuk protokol MQTT dan HTTP.

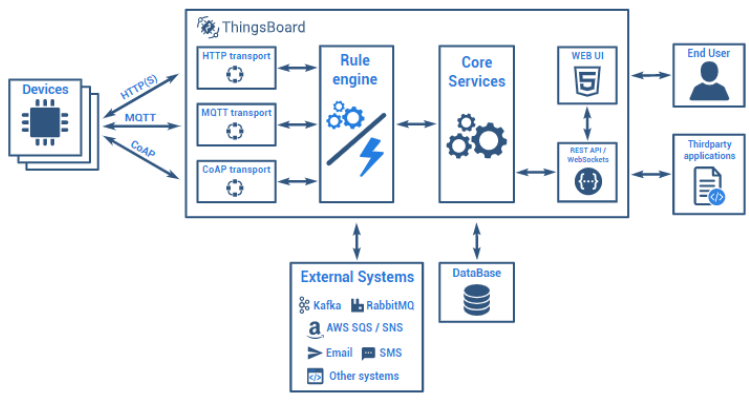

Gambar 1. Desain Arsitektur ThingsBoard

\subsection{VirtualBox}

Oracle VM VirtualBox a da lah perangkat lunak virtualisa si, yang dapat digunakan untuk mengeksekusi sistem operasi tambahan di dalam sistem operasi utama. VirtualBox berfungsi untuk melakukan virtualisasi sistem operasi. VirtualBox juga dapat digunakan untuk membuat virtualisasi jaringan komputer sederhana. Penggunaan VirtualBox ditargetkan untuk Server, desktop dan penggunaan embedded. Untuk menjalankan VirtualBox spesifika si minimum yaitu : Prosesor dengan kecepatan $1 \mathrm{GHz}$ a tau yang lebih cepat, baik yang 32 bit (x86) atau 64-bit (x64), 1 GB RAM untuk sistem 32-bit atau 2 GB RAM untuk sistem 64-bit, 16 GB ruang hardisk untuk sistem 32-bit atau 20 GB untuk sistem 64-bit, VGA yang telah mendukung DirectX 9 graphics device dengan WDDM 1.0 atau driver yang lebih tinggi[5].

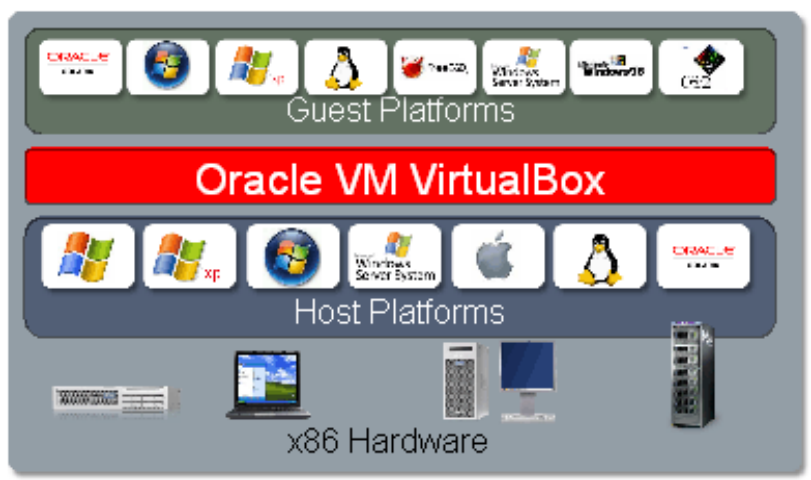

Gambar2. Desain Arsitektur VirtualBox

\subsection{Ubuntu Server}

Sistem opera si ubuntu server da pat dipa sang pa da beberapa tipe arsitektur komputer diantaranya Intel X86, AMD64, ARM, SPARC, PowerPC, Itanium64. Ubuntu server memiliki kebutuhan sistem minimum yang harus yang harus dipenuhi diantaranya adalah : Prosesor 300Mhz, Memory 64MB, HDD 500MB, VGA $640 \times 480$

\subsection{Instalasi ThingsBoard di Ubuntu Server}

Panduan ini menjelaskan cara menginstal ThingsBoard di Ubuntu 18.04 LTS / Ubuntu 20.04 LTS. Persyaratan perangkat keras tergantung pada database yang dipilih dan jumlah perangkat yang terhubung ke sistem. Untuk menja lankan ThingsBoard dan PostgreSQL pada suatu mesin, diperlukan setidaknya 1 Gb RAM. 
Sedangkan untuk menjalankan ThingsBoard dan Cassandra pada suatu mesin, diperlukan setidaknya $8 \mathrm{~Gb}$ RAM.

\subsubsection{Install Java 11 (OpenJDK)}

ThingsBoard Service berjalan di Java 11. Untuk bisa menggunakannya, lakukan instruksi berikut untuk install OpenJDK 11

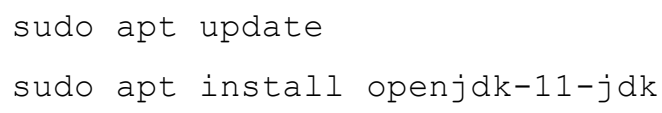

perintah update digunakan untuk mengupdate ubuntu server, dan install openjdk digunakan untuk mendownlaod library Java 11. Apabila perintah sudah dibuat di command line ubuntu server, tunggu proses instalasi Java selesai. Setelah selesai akan muncul seperti gambar berikut

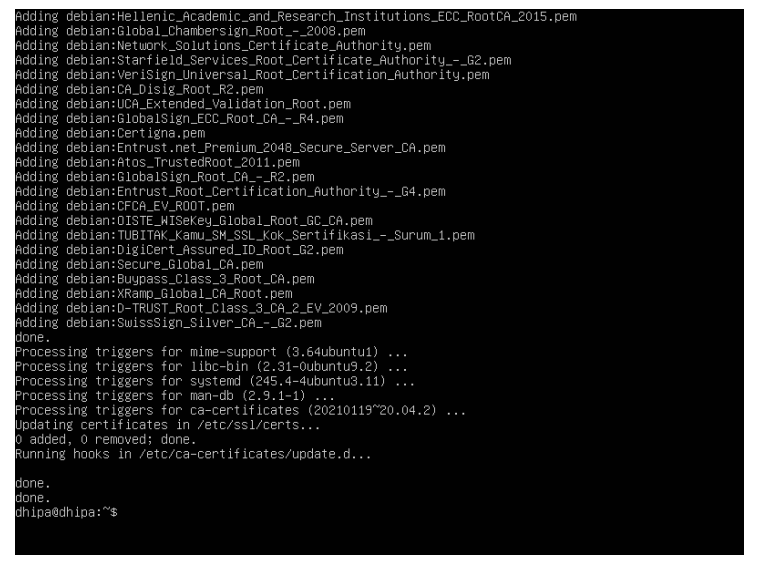

Gambar3. Instalasi Java 11 di Ubuntu Server

Setelah selesai menginstall, langkah selanjutnya yaitu mengkonfigurasi Ubuntu Sever untuk menggunakan OpenJDK 11 secara default. Konfigura si menggunakan perintah berikut

sudo update-alternatives --config java

Setelah selesai melakukan perintah diatas, lakukan perintah cek versi java dengan perintah berikut java -version

Saat melakukan pengecekan versi Java, command line yang keluar diharapkan sepertiberikut

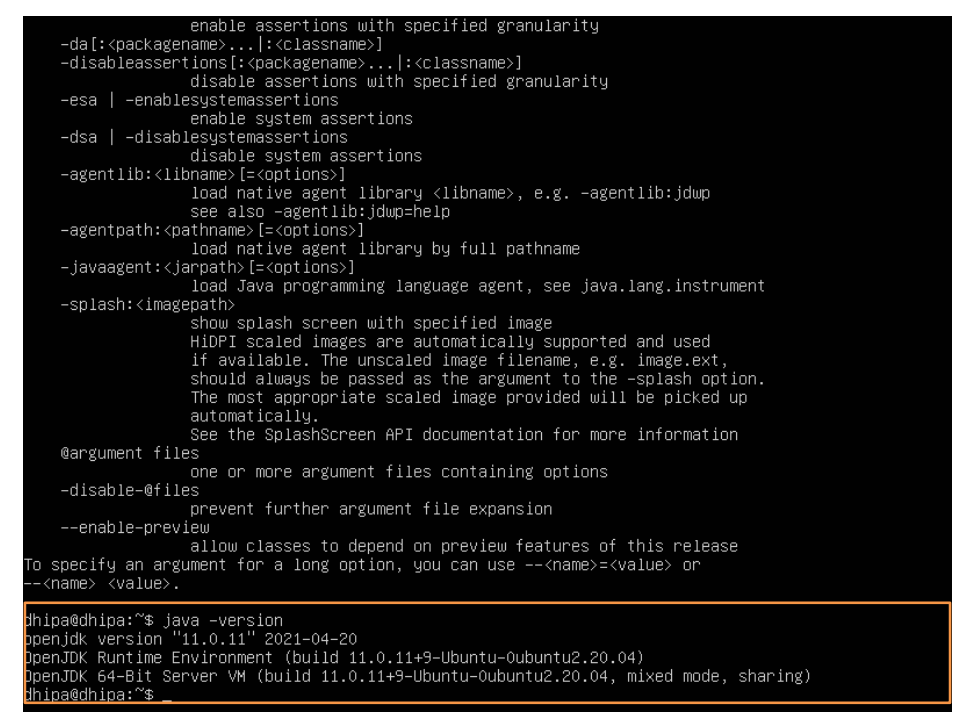

Gambar4. Output akhir Instalasi Java 11

\subsubsection{Install Thingsboard Service}


Untuk menginstall Thingsboard Service, hal pertama yang harus dilakukan adalah menginstall packagenya terlebih dahulu, untuk menginstall packagenya gunakan perintah berikut

wget

https://github.com/thingsboard/thingsboard/releases/download/v3.3.2/t hingsboard-3.3.2.deb

Tunggu proses instalasi selesai, Setelah selesai menginstall package thingsboard, gunakan perintah berikut untuk menginstall thingsboard sebagai service

sudo dpkg -i thingsboard-3.3.2.deb

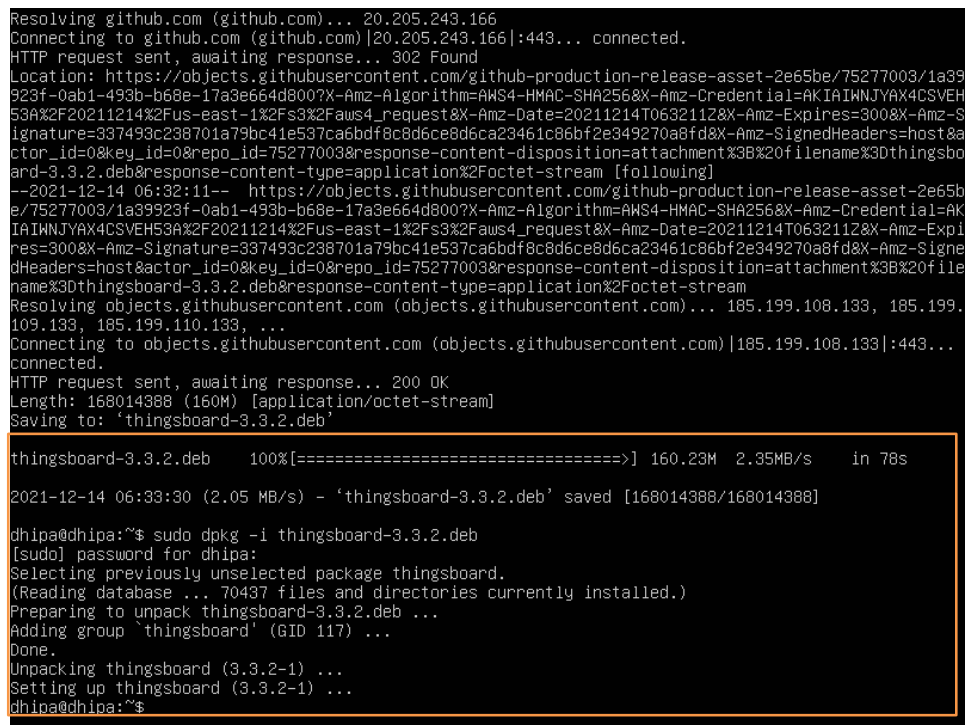

Gambar 5. Output akhir Instalasi Thingsboard Service

\subsubsection{Konfigurasi Database di Thingsboard}

Pada saat melakukan konfigura si Database, ada tiga pilihan yang diberikan untuk databasenya yaitu PostgreSQL, Hybrid Database (PostgreSQL+Cassandra), dan Database untuk professional (PostgreSQL+TimescaleDB). Ketiga Database ini digunakan untuk keperluan sesuai kebutuhan. PostgreSQL digunakan untuk pengembangan Database yang tidak terlalu besar (<5000 msg/sec), sedangkan Hybrid Database (PostgreSQL+Cassandra) digunakan untuk data dia tas $(>5000 \mathrm{msg} / \mathrm{sec}$ ) dan da tabase ini digunakan untuk perangkat yang nanti kedepannya diperkirakan memiliki 1 juta perangka t. Untuk Database professional (PostgreSQL+TimescaleDB) digunakan oleh suatu perusahaan yang sudah berproduksi secara massal.

Databa se yang digunakan untuk Konfigura si Databa se sekarang menggunakan PostgreSQL, perintah yang digunakan seperti berikut

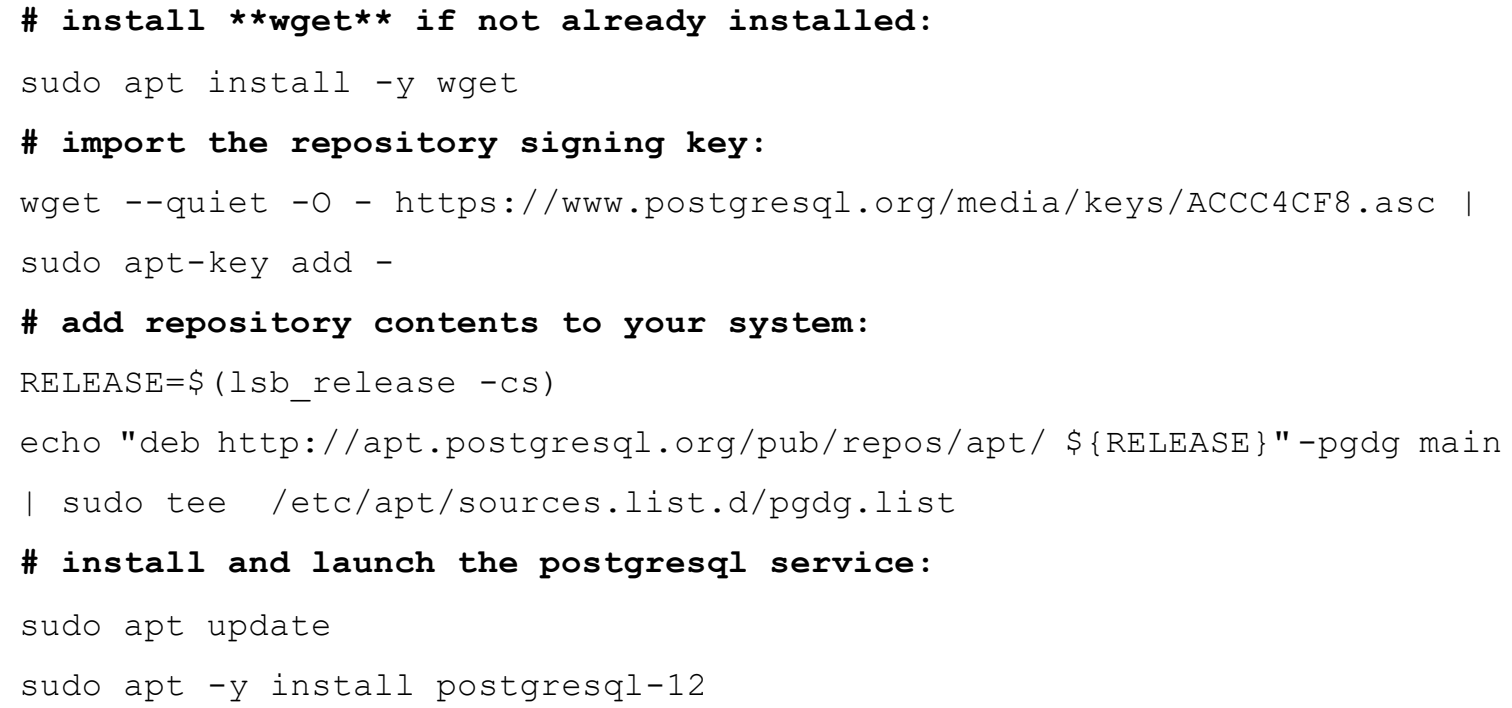


sudo service postgresql start

Setelah selesai menginstall Postgresql, langkah selanjutnya membuat user baru dan mensetting password untuk user baru. Untuk dapat melakukannya gunakan perintah berikut
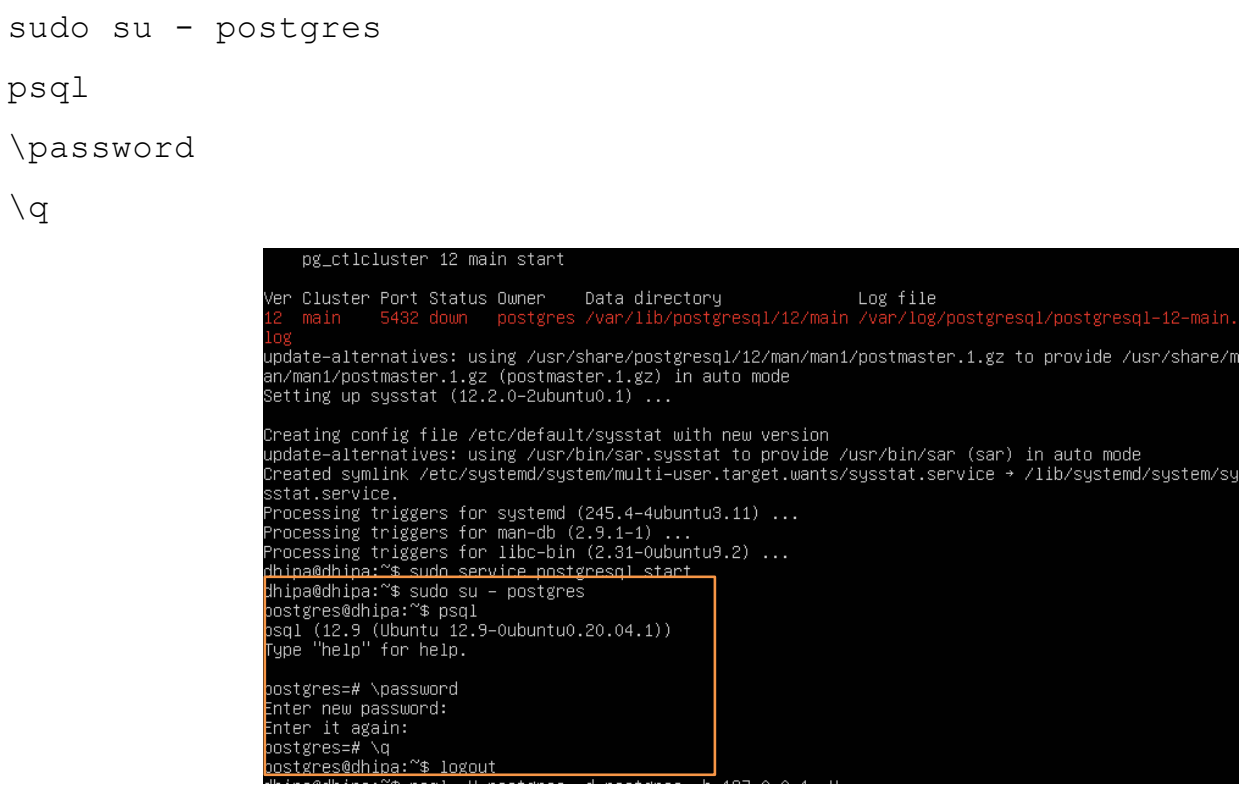

Gambar 6. Usernama dan Password Postgresql

Lalu ketik secara bersamaan di Keyboard CTRL+D untuk kembali ke main user dan melakukan perintah untuk melakukan koneksi ke database dan membuat thingsboard database. Perintah yang digunakan adalah

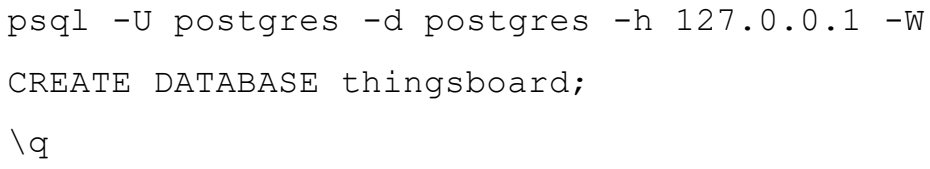

Setelah selesai membuat database dithingsboard, langkah selanjutnya yang dilakukan yaitu mengkonfigurasi Database thingsboard. Perintah yang digunakan adalah

sudo nano/etc/thingsboard/conf/thingsboard.conf

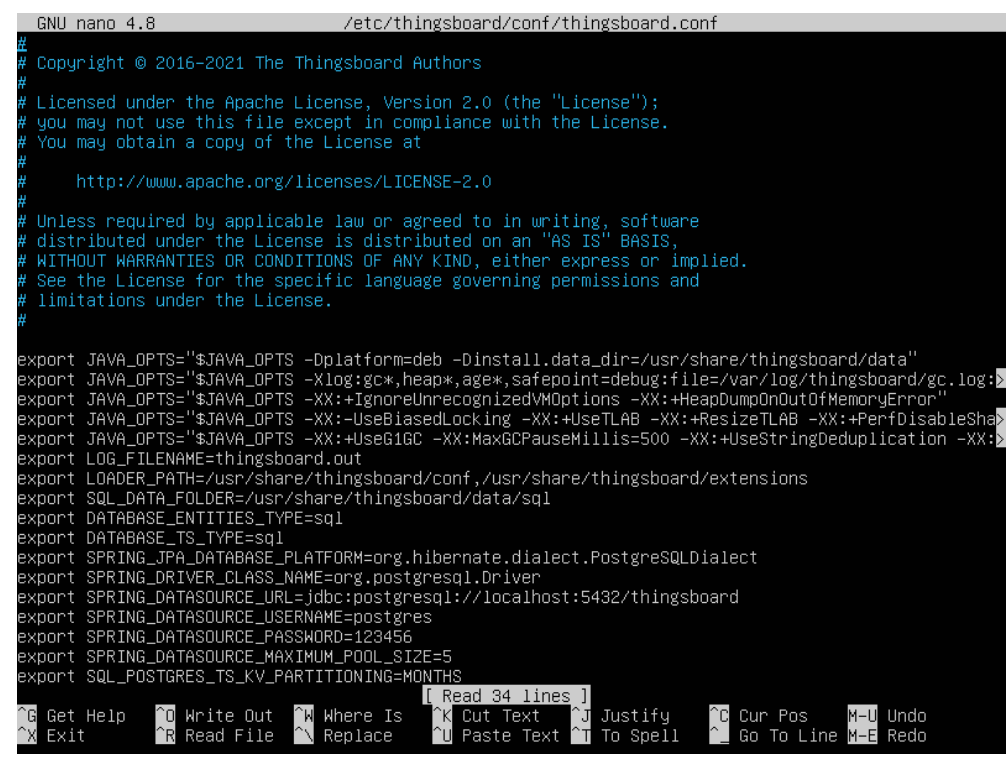

Gambar7. Perintah nano, nano merupakan teks editor di Sistem Opera si Linux 
Jika sudah melakukan perintah diatas, langkah selanjutnya a dalah mengketik dikonfigura si file perintah berikut
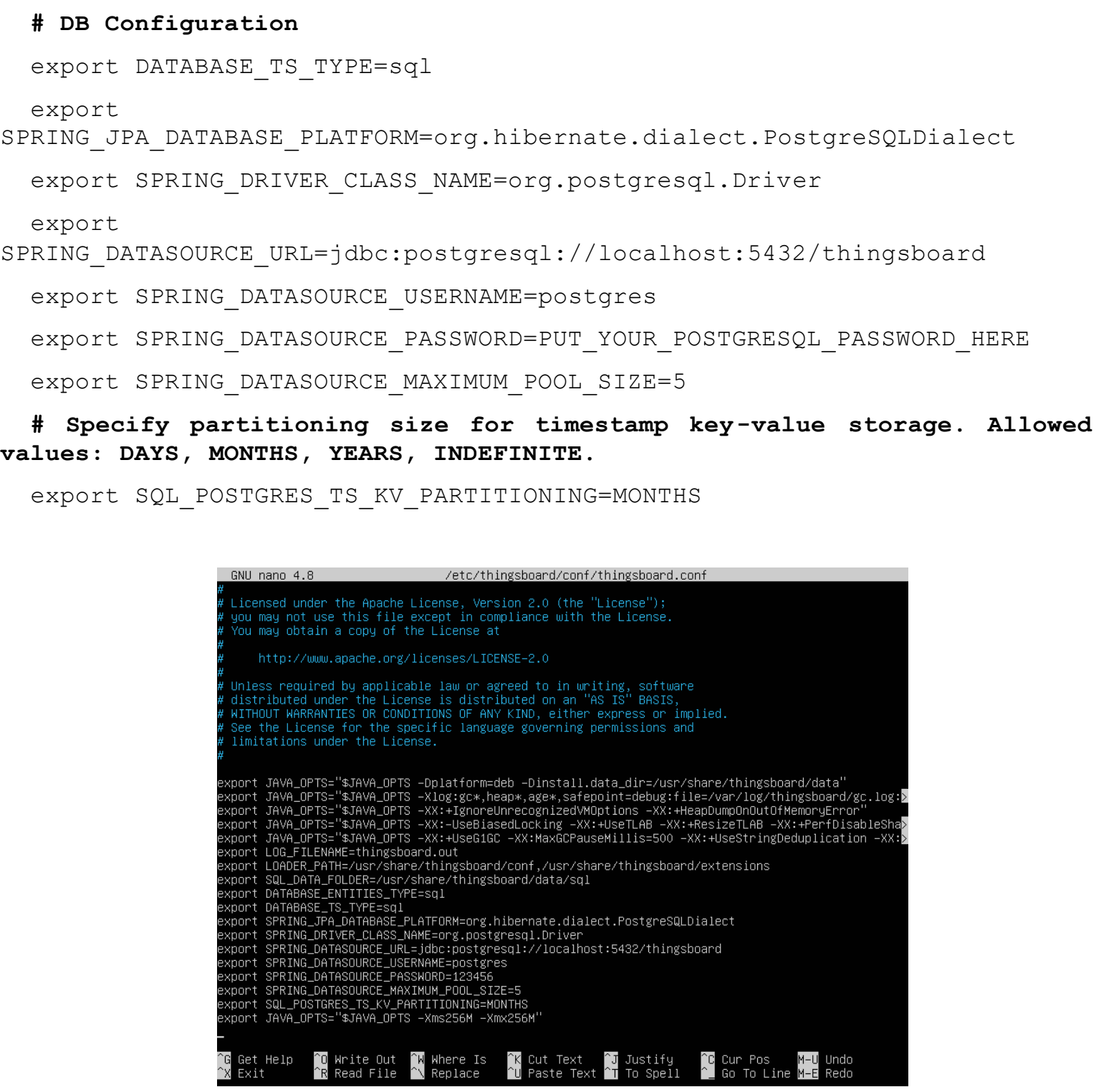

Gambar 8. Hasil dari perintah

\subsubsection{Memilih Penyimpanan queue diThingsboard}

ThingsBoard dapat menggunakan berbagai sistem/broker pesan untuk menyimpan pesan dan komunikasi antar layanan ThingsBoard. Ada tujuh macam penyimpanan yang bisa dipilih, tergantung dari kebutuhuan yang diinginkan. Apabila hanya untuk melakukan development suatu alat / Proof of concept (Poc) Menyimpan di memori merupakan pilihan yang tepat, sedangakan pilihan yang lain seperti menggunakan kafka, RabbitMQ, AWS SQS, Google Pub/Sub, Azure Service Bus, dan Confluent Cloud merupakan penyimpanan/layanan yamg lebih tepatnya digunakan untuk suatu alat yang sudah siap di produksi secara massal. Jika memilih In Memory queue, tidak ada konfigurasi yang harus dilakukan karena In Memory queue sudah diaktifkan secara default.

\subsubsection{Melakukan perintah Run Script}

Apabila proses melakukan Instalasi, Membuat Database di Thingsboard sudah selesai, ketikan perintah berikut untuk melakukan Run Thingsboard

\#loadDemo option will load demo data: users, devices, assets, rules, widgets.

sudo/usr/share/thingsboard/bin/install/install.sh -loadDemo 

berikut

Setelah selesai, lakukan perintah berikut untuk menjalankan Thingsboard Service, lakukan perintah

sudo service thingsboard start

\section{HASIL DAN PEMBAHASAN}

3.1. Hasil akhir dari proses Insta lasi

Untuk melihat Website UI Thingsboard di Ubuntu Server, yang harus dilakukan adalah membuka Browser Web Firefox bawaan dari Ubuntu, lalu ketik di search bar: http: / / local host: 8080/ digunakan :

Untuk username dan password sendiri sudah di sediakan darithingsboard, ada tiga pilihan yang bisa

- System Administrator: sysadmin@thingsboard.org / sysadmin

- Tenant Administrator: tenant@thingsboard.org/tenant

- Customer User: customer@thingsboard.org / customer

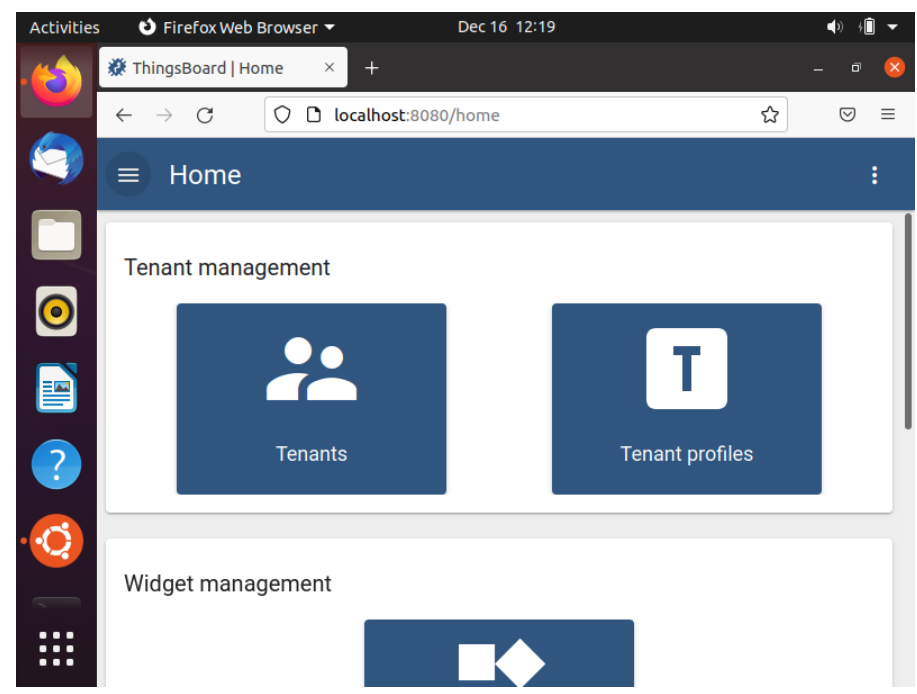

Gambar9. Hasil yang di dapat saat melakukan proses diatas

\subsection{Kelebihan menggunakan Server Ubuntu}

Linux Ubuntu, adalah sistem operasi yang berdiri di atas lisensi open source. Artinya sistem operasinya bebas digunakan untuk setiap orang, dan tidak perlu membeli lisensi seperti yang ada di sistem operasi Windows. Selain itu, setiap orang bebas melakukan kontribusiuntuk mengembangkan sistem opera si ini menjadi lebih baik di masa depan. Selain itu UI yang diberikan Ubuntu sangat cocok digunakan untuk pemula yang ingin mencoba menggunakan Linux untuk pertama kalinya. Selain itu, Ubuntu juga dilengkapi dengan driver dan Aplikasi bawaan yang lengkap, salah satu contohnya apabila menginginkan sistem operasi dengan tujuan khusus seperti untuk melakukan penetration testing, aplikasi yang diperlukan bisa jadi telah diinstal sejak awal sehingga tidak perlu mempersiapkan aplikasitambahan la gi.

\subsection{Kekurangan menggunakan Server Ubuntu}

Bagi user / pengguna baru sistem operasi Ubuntu Server, dibutuhkan adaptasi untuk tampilan GUI (Graphic User Interface) yang diberikan. User juga harus mempelajariterlebih dahulu men genaipenggunaan terminal, root, dan berbagai masalah lainnya yang mungkin belum pernah ditemukan ketika menggunakan sistem operasi seperti Windows. Di beberapa kasus, hal ini dapat menyulitkan para pengguna terutama yang ingin mendapatkan pengalaman perta ma yang mudah. Hal ini dapat diatasi dengan belajar menggunakan Ubuntu tersebut dan seiring berjalannya waktu akan terbia sa menggunakan sistem opera sitersebut. 


\subsection{Keamanan Ubuntu Server sebagaiPlatform}

Sistem Linux mempunyai keuntungan utama yang terletak pada cara pemberian hak akses istimewa terha dap akun yang akan ditetapkan. Di Windows, user bia sanya diberi akses administra tor secara default, yang berarti mereka cukup banyak memiliki akses terhadap semua haldi sistem, bahkan bagian yang paling penting sekalipun. Jadi, apabila menginstall suatu virus, virus pada umumnya akan meminta hak administrator Windows. Halini dapat berujung ke virus memiliki hak akses ke sistem.

Apabila menggunakan Linux, user biasanya tidak memiliki hak "root" a tau admin. Sebaliknya, user bia sanya akan diberiakun dengan tingkat akses sistem yang rendah. Artinya a pabila sistem terkena virus, virus tidak akan memiliki akses root yang dibutuhkan untuk melakukan kerusakan di seluruh sistem. Mungkin hanya file lokal user dan program saja yang akan terpengaruh. Hal ini akan sangat membuat perbedaan antara gangguan kecil dan maupun kerusakan besar contohnya a pabila server digunakan di da lam lingkungan bisnis.

\section{KESIMPULAN}

Dalam uraian diatas dapat disimpulkan bahwa Ubuntu Server merupakan suatu operasi sistem yang sangat berguna dan memiliki sifat open source yang sangat berguna bagi setiap orang. Apabila Ubuntu Server dirasa kurang user friendly karena tampilan GUI (Graphic User Interface) yang hanya berupa baris perintah, Di Ubuntu Server ini juga bisa mendownload GUI untuk pemula yang ingin mencoba menggunakan Ubuntu Server. Hal ini akan membuat Ubuntu Server mera sa lebih mudah digunakan walaupun penggunaan RAM akan meningkat. Untuk instalasi Thingsboard di Ubuntu Server sendiri akan sangat aman mengingat di Ubuntu Server memiliki tingkat keamanan yang relatif tinggi dan adanya Komunitas di Ubuntu membuat suatu permasalahan mengenai Ubuntu Server bisa diselesaikan. Apabila sudah mempunyai DNS (Domain Name Server) di Thingsboard, Di Ubuntu Server bisa menambahkan HAProxy, HAProxy atau High Availability Proxy adalah sebuah perangkat lunak open source dibawah GPLv2 license. HAProxy ini berfungsi untuk membagibeban request ata load balancer TCP/HTTP, sehingga beban Server tidak terla lu berat dan tingkat kea manan Server yang meningkat karena menggunakan Proxy.

\section{UCAPAN TERIMAKASIH}

Ucapan terima kasih disampaikan oleh penulis kepada Tuhan Yang Maha Esa yang telah memberi semua anugerahnya sehingga dapat melancarkan semua proses demi proses dalam pembuatan artikel ini. Tidak lupa penulis juga mengucapkan terima kasih banyak kepada bapak I WAYAN ADITYA SURANATA S.T.,M.T. selaku dosen pengampu dari kegiatan Kerja Praktek yang sudah bersedia membimbing dalam kegiatan Kerja Praktek ini serta tidak lupa selalu memberi arahan sehingga ilmu yang dida patkan dapat diimplementa sikan mela lui artikel ilmiah ini.

\section{DAFTAR RUJUKAN}

[1] Rahmat Tullah, Sutarman, Agus Hendra Setyawan (2019). Sistem Penyiraman Tanaman Otomatis Berbasis Mikrokontroler Arduino Uno Pada Toko Tanaman Hias Yopi. JURNAL SISFOTEK GLOBAL, Vol. 9 No. 1

[2] Yoyon Efendi (2018). INTERNET OF THINGS (IOT) SISTEM PENGENDALIAN LAMPU MENGGUNAKAN RASPBERRY PI BERBASIS MOBILE. Jurnal Ilmiah Ilmu Komputer, Vol. 4, No. 1

[3] Harindra Wisnu Pradhana (2010). Ubuntu Server. TELKOMNIKA, Vol.12, No.2

[4] Thingsboard "Installing Thingsboard CE on Ubuntu Server". https://thingsboard.io/docs/user-guide/install/ubuntu/

[5] AGUNG GALIH SETIAWAN (2014). ANALISIS PADA JARINGAN KOMPUTER DENGAN METODE VIRTUALISASI. Dokumen Karya Ilmiah, Tugas Akhir, Program Studi Teknik Informatika - S1, Fakultas Ilmu Komputer, Universitas Dian Nuswantoro Semarang

[6] Kadek Jeny Femila Devi, I Ketut Resika Arthana, I Gede Mahendra Darmawiguna (2015). Pengembangan Distribusi Luxpati Berbasis Ubuntu Sebagai Penunjang Proses Belajar Mengajar di Jurusan Pendidikan Teknik Informatika, Volume 4, Nomor 3 